\title{
VULNERABILITY ANALYSIS OF TURKISH BANKS USING STRESS TESTING AND INTERNAL CREDIT RATING APPROACH
}

\author{
DOI: 10.17261/Pressacademia.2020.1207 \\ JEFA- V.7-ISS.2-2020(4)-p.103-119
}

\section{Masoud Ghazavi ${ }^{1}$, Sema Bayraktar Tur ${ }^{2}$}

${ }^{1}$ Financial Specialist, Bank Mellat Headquarters, Tehran, Iran. ghaz1370@yahoo.com, ORCID: 0000-0002-3973-1076

${ }^{2}$ Istanbul Bilgi University, Department of Banking and Finance Istanbul, Turkey. sema.bayraktar@bilgi.edu.tr, ORCID: 0000-0002-7564-4148

Date Received: April 2, 2020

Date Accepted: June 15, 2020

To cite this document

Ghazavi, M., Tur, S.B, (2020). Vulnerability analysis of Turkish banks using stress testing and internal credit rating approach. Journal of Economics, Finance and Accounting (JEFA), V.7(2), p.103-119.

Permanent link to this document: http://doi.org/10.17261/Pressacademia.2020.1207

Copyright: Published by PressAcademia and limited licensed re-use rights only.

\section{ABSTRACT}

Purpose- This study examines the performance and financial vulnerability of twelve Turkish banks for 2019.

Methodology - Stress testing identifies the impact of extreme expected and unexpected shocks to a bank's capital, provides an assessment of its financial strength to withstand shocks and helps to spot emerging risk(s) and uncover weak spots in the financial institution. It enables banks in identifying their vulnerabilities at an early stage. In addition to stress testing, as for Internal Credit Rating (ICR), some financial ratios have been selected to assess the performance of each bank within banking industry.

Findings- All banks in 2019 are within the standard classification of ICR rating except for Şekerbank. However, results show that not all banks are resilient to stress testing implemented in the study.

Conclusion- This study shows that Turkish banks are on the knife edge. The results show that the critical factor that may result in the insolvency of the banks is NPLs. Thus, Turkish regulators should take measures that would prevent banks to take any action that would increase their NPLs both in the short and long term.

Keywords: Performance analysis of banks, internal credit rating (ICR), stress testing (ST), sensitivity analysis, scenario analysis. JEL Codes: G21, G32, E37

\section{INTRODUCTION}

Banks are assumed as the most important financial intermediaries that mobilize resources from savers and allocate them to the borrowers/spenders in an efficient way. Efficient financial markets and strong financial institutions are indispensable to sustainable development. There is no developed country in the world which experiences sustainable development without having already established efficient financial intermediaries. To prepare the ground for improvement of the efficiency among financial intermediaries, one needs a mechanism that can distinguish between the better and the worse. One way to achieve this goal is to use Stress Testing and Internal Credit Rating (ICR). This way the regulators not only can distinguish between different banks in terms of soundness, strength, and sustainability but also, they can prevent/mitigate bank crisis by imposing prudential recommendations and policies on the banks which show any kind of prudential weakness.

The main role of Internal Credit Rating (ICR) is to determine the probability of default for a financial institution. Internal Credit Rating is a function which comprises of two main domains namely "Credit Scoring" and "Credit Rating". The focus of the study would be on Credit Rating, not on Credit Scoring. Stress Test, on the other hand, is a risk management tool to assess the vulnerability of counterparties to exceptional conditions. For stress testing, normally two techniques are used: namely Sensitivity Analysis and Scenario Analysis. For sensitivity analysis, each individual variable is changed separately while other variables held constant. For each variable changed, three levels of shocks are considered namely as minor, moderate and major shock. The variables considered are as follows: rise in NPLs to Total Loans ratio, decline in lending rate, rise in borrowing rate, depreciation in TRY. In the case of scenario analysis, the scenarios have been constructed with the combination of three major changes; rise in NPLs to Total Loans Ratio, rise in borrowing interest rate and depreciation of TRY against USD and Euro. 
Then based on some weighted selected ratios, internal credit ratings (ICR) have been computed. ICR is a measurement for evaluating a bank's performance and gives us a chance to observe banks based on this score before and after shocks implemented.

This study will focus on the Turkish banking sector. Turkey as a developing country undertook a series of banking reforms, adapting risk management rules commonly accepted in the global banking system, after nation's 2001 banking crisis. These reforms have strengthened the Turkish banks so that they were able to keep their required capital ratios well above the globally accepted rates. However, unlike some other major regulators worldwide such as European Banking Authority, stress testing results are not publicly declared by Banking Regulation and Supervisory Authority (BRSA) in Turkey. Thus, whether Turkish banks can endure the given adverse economic scenarios is an important question to be answered. As of December 2019, there are 47 banks working under BRSA. Thirty-three (34) of these banks are Deposit banks and the rest, thirteen (13) of them are Development and Investment banks. Deposit banks consist of three (3) state-owned deposit banks, nine (9) private-owned deposit banks, twenty (21) foreign banks and one (1) bank is under the Deposit Insurance Fund's control. (www.tbb.org.tr). The main purpose of this study is to analyze the performance of selected Turkish banks by observing current ICR ratings and possible ICR ratings under different stress testing scenarios. For that purpose, twelve banks are chosen: three state-owned deposit banks, five private-owned deposit banks and four foreign banks. The banks in the sample are Ziraat Bank, Halkbank, İşbank, Vakıflar Bank, Garanti Bank, Yapı and Kredi Bank, Akbank, QNB Finansbank, Türk Ekonomi Bank, ING Bank, Odea Bank and Şekerbank ${ }^{1}$

Next section summarizes the relevant literature. Third section explains the methodology used in the present study in detail. Following methodology, ICR rating comparisons for sample banks are comprehensively discussed in the fourth section of the study. The last section evaluates the implications of the results for Turkish Banking sector.

\section{LITERATURE REVIEW}

There are many guidelines published by different country regulators in the literature that just analyze the stress testing methodologically. These guidelines define stress testing, try to construct framework(s) for it, and may implement some kind of stress testing at a macro or micro level to the banking sector of the relevant country (ies).

For example, Committee of European Banking Supervisors (CEBS) published a guideline (2010) which used four different methodologies for stress testing: Sensitivity analysis, Scenario analysis, Severity of scenarios and Reverse stress testing. Bank for International Settlements (2017) released a paper on supervisory and bank stress test which compared related practices and highlighted areas of evolution based on two separate surveys run through 31 authorities and 54 respondent banks. This report comprised of two stress testing frameworks: one for authorities and one for banks. It showed that supervisory authorities started to allocate more resources to enhance stress testing regulations. Banks also have improved their governance structure through implementations of stress testing.

European Banking Authority has also published a guideline on institutions' stress testing (2018) which mandates institutions to put in place stress testing program with specifications such as: types and frequencies of stress testing, internal governance arrangements, relevant data infrastructure and methodological details. Guideline on Stress Testing published by Office of Superintendent of Financial Institutions of Canada (OSFI) (2009) just defined credit risk, counterparty risk, other risks and explained sensitivity testing and scenario testing. On the other hand, Guideline on Stress Testing published by Bangladesh Bank Department of Offsite Supervision (2010) has designed a framework for banks and financial institutions to manage risks in accordance with international best practices. They have developed a vulnerability measurement called Internal Credit Rating and implemented this framework to measure the strength of individual banks. Another "Guidelines on Stress Testing"

released by State Bank of Pakistan (2012) has demonstrated techniques for stress testing and on how to implement and analyze shocks (such as a rise in NPLs) that could change financial position of a financial institution. This guideline as a benign concentration on sensitivity and scenario analysis considered only credit risk and market risk. It illustrated the impact of stress testing considering three levels of shocks: minor, moderate and major.

There are also empirical studies that have analyzed the vulnerability of banks and/or banking sector to the changes in macroeconomic variables. For example, the master thesis study done by Tatjana Vukelí c (2011) illustrated macro stress tests and conducted stress testing for credit and market risks for 9 banks in Croatia and 10 banks in Serbia. In this study, shocks have been linked to macroeconomic variables such as GDP and interest rate. The researcher has concluded there are some banks that faced problems with fulfilling the regulatory minimum capital requirements in case of baseline and the adverse

\footnotetext{
${ }^{1}$ Basically the banks with total assets higher than 5 billion USD were selected as the sample, except Denizbank and HSBC which did not publish their financial statements at the time the study conducted.
} 
scenarios. The results of this research showed that in Croatia under the baseline scenario, one foreign-owned bank had Capital Adequacy Ratio (CAR) below the regulatory minimum level of $12 \%$. Under the adverse scenario, it appeared that two more banks had fallen below threshold. In this last scenario, it was found that approximately $0.27 \%$ of the GDP of Croatia in year 2009 was needed to fulfill the minimum capital adequacy ratio of $12 \%$ for the banks under study. Similar results have been reached by implementing baseline and adverse scenarios to the Serbian banks. In the case of Serbia, $0.33 \%$ of the Serbia's GDP in 2009 was needed to fulfill the minimum requirement of capital adequacy for the banks under study which cover $70 \%$ of the banking sector.

K. Virolainen, in his study, (2004) discussed macro stress testing with a macroeconomic credit risk model for Finland. The model has been applied to assess corporate sector bankruptcy probability from 1986 to 2003 in Finland. The results of the stress tests offer that Finnish corporate sector credit risks are limited during the sample period.

G. Hoggarth et al. (2005) illustrate stress tests of UK banking system using Vector Auto Regression (VAR) approach to estimate the impact of changes in macroeconomic variables on banks' aggregate losses since the late 1980 s and sectorial losses since the early 1990s. This paper uses the write-off to loan ratio as a direct measure for bank vulnerability. It shows that after a shock to the output gap similar to one which happened in early 1990s, the aggregate write-off ratio of UK banks increases by around 0.7 percentage points which indicates that the UK banking system as a whole withstand relatively satisfactorily to enormous adverse macroeconomic shocks.

A study published by R. Filosa (2007), titled as "Stress testing of the stability of the Italian banking system: a VAR approach" also applies Vector Auto Regression (VAR) to measure procyclicality of the Italian banking sector which shows non-performing loans or interest margins are weakly procyclical. This research concludes that if monetary policy gets tightened, the Italian banks' soundness indicators experience small changes.

Another research done by J. Zeman and P. Jurca (2008) used Vector Error Correction model. This study evaluates the relationship between macroeconomic variables and the quality of loan portfolio in the Slovak banking sector. Some variables such as real GDP has been considered. The results show that slowdown of the GDP growth would not considerably affect the Slovak banking sector if adequate monetary policy is taken into place.

A macro stress testing on loan portfolio of Japanese banks (2009) done by A. Otani et al. expresses a framework which has been used by the Bank of Japan (BOJ) for macro stress-testing on credit risk. This framework accesses the strength of loan portfolios for major banks and regional banks against a severe economic shock. The simulation results show asymmetric responses of credit risk between deep recession and subsequent economic recovery.

Z. Fungáčová and P. Jakubík (2012) published a case study of 200 largest Russian banks in which they have analyzed resilience of these banks by implementing a top-down stress test. In this study two scenarios have been taken into consideration. One a baseline scenario and the other one is the adverse scenario. Both scenarios emphasize the need of capital increase in Russian banking sector.

Mohd. Moshin and Md. A. Kamal (2012) investigate stress test theoretically and then employ stress testing of credit, equity, and liquidity shocks of ten commercial banks of Bangladesh. The results show that eight banks are in good position against liquidity shocks and five banks are resilient against the equity shock. Credit (NPLs) shock results varied with respect to different level of shocks.

O. Kamenik et al. (2013) applied a stress testing model for the Austrian, Czech and German economies in order to evaluate the strength of fiscal positions concentrating on a baseline scenario and considering some alternatives to check the outcomes. Results, among others, show that all three economies responded to the financial crisis by a mix of short-term fiscal expansion and medium-term contractionary policy.

Although there are many studies on stress testing of banks worldwide, the studies on Turkish banking sector are limited. For example, the research done by Ç. Başarır and C. Toraman (2014) is a methodological paper which discusses stress testing as a way to assess level of financial stability and explains related variables which should be taken into account to run the stress testing.

The studies on Turkish banks, like their international researches, also analyze the impact of macro-economic variables on the financial ratios of the banks but do not use any vulnerability measurement before and after stress testing. For example, Ph.D. dissertation done by B. Çakmak (2014) uses several independent and complementary models in order to run a macro stress test for Turkish banking sector in terms of credit risk. First model establishes a relationship between macroeconomic variables and macro financial variables within a VAR (Vector Autoregression) framework. Second model regresses nonperforming loans to macroeconomic and macro financial variables by using static and dynamic panel data techniques. He finds that nonlinear 
models perform better than linear models and the banking sector is resilient to external shocks under the related scenarios by looking at non-performing loans and change in capital adequacy ratio.

S. Önder et al. (2015) used a top-down macro stress testing related to Turkish banking sector as a whole. Credit risk satellite model quantifying the credit risk illustrates that economic growth, exchange rates and unemployment rate had significant impacts on corporate NPL while exchange rates had no statistically significant impact on retail NPL.

Moreover, another study by Ç. Başarır (2016) measures stability of the Turkish Banking Sector against financial crisis by using a credit risk model while implementing 3 different assumptions and a satellite model. In the first step he has applied a macroeconomic VAR model to determine the relationship between the macro variables. Also analyzing non-performing loan ratio against some unexpected situations. Then he concluded that the banking sector is resilient to the shocks like 2001 crisis.

There are many important points that separates this study from the previous ones in Turkish banking sector. This study is the first one that combines stress testing method with internal credit rating measure to do a vulnerability analysis to individual Turkish banks. By doing so, the study can compare the financial positions of an individual bank before and after the shock implemented. The study also conducts both sensitivity and scenario analysis to be able to observe individual and total effect of changes. This is important because sometimes the combined effect can be greater than the summation of individual effects. Also, the study is being conducted at the break of a global crisis, thus it is important whether the banks under study would be resilient against any possible shock that may occur due to the inevitable result of this crisis.

\section{DATA AND METHODOLOGY}

\subsection{Stress Testing (ST)}

Stress Test is a risk management tool used to assess the vulnerability of counter- parties to exceptional events. It identifies the impact of extreme expected and unexpected shocks to the counterparty's capital, provides an assessment of its financial strength to withstand shocks and to spot emerging risk(s) and uncover weak spots in the financials. It enables counterparties in identifying their vulnerabilities at an early stage. "Stress test helps to identify and analyze the risks which might be latent under benign conditions but, if triggered, could have serious implications for the very existence of a financial institution." (State Bank of Pakistan , 2012)

In terms of methodologies, normally two techniques are used for stress testing: Sensitivity Analysis and Scenario Analysis. Sensitivity Analysis measures the short-term effect of a change in a key variable under different levels of shock, namely minor, moderate, and major shocks while holding other variables constant. Key variables may include changes in variables including decline in net interest rate margin (NIM), decline in lending rate, rise in NPLs to Total Loans ratio, rise in borrowing cost, increase in operating expense etc. The sensitivity analysis looks at the impact of these changes on the overall financial position of the borrower and on the internal credit rating (ICR). Scenario Analysis, on the other hand, examine the effect of excessive but plausible scenarios on the financial position of the counterparty. Scenarios could be historical events such as stock market crash, regional turmoil, currency depreciation, natural disasters or any hypothetical event that may be extreme but not improbable to occur. Macro stress testing has become a popular tool for supervisors to examine weaknesses of the overall financial system. In addition, some financial institutions use macro stress testing in purpose of their internal credit risk models. (State Bank of Pakistan , 2012)

Financial institutions design their own scenarios using either a portfolio-driven approach or an event-driven approach. The former approach starts with risk identification at the portfolio level and then works backwards to conceive plausible scenarios which would cause identified risks to materialize. Scenarios can be hypothetical (based on expert judgment) or historical like the global financial meltdown in 2008. Possible scenarios that may be taken into account include macro-economic slowdown, political or regional turmoil, un-professional management and natural disasters (floods, earthquakes) (State Bank of Pakistan , 2012).

In this study for Stress Testing, two approaches have been applied; one is sensitivity analysis and the other one is scenario analysis. For both approaches, prior and subsequent positions have been compared. First, for sensitivity analysis, four different variables with three levels of specific shocks have been assumed. The variables considered are as follows: rise in NPLs to Total Loans ratio, decline in lending rate, rise in borrowing rate and depreciation in Turkish Lira (TRY). Their impacts on Income Statement and Balance Sheet have been measured. Second, in case of scenario analysis three level of shocks have been used: a rise NPLs to Total Loans Ratio, a rise in borrowing interest rate and a depreciation in TRY against USD and Euro.

ICR is relied upon two parts: Quantitative Assessment and Qualitative Assessment. ICR based on these quantitative and qualitative assessments allocates a score for a typical bank. It is a measurement for evaluating a bank's performance and gives us a chance to compare banks based on this score. ICR is scaled between 1 and 10, where 1 is the best score and 10 is 
the worst. Score 1 to 6 indicates that bank's situation is "Standard". 7, 8 and 9 scores mean "Watchful", "Sub-standard" and "Doubtful" respectively. Finally, score 10 is the worst situation for a typical bank meaning that it is under a distressed situation. In other words, score 10 shows that bank is in a serious financial difficulty.

Quantitative Assessment with a weight of $70 \%$ of total assessment is based on five categories each of which is determined by some specific financial ratios. Some of these ratios are positively and some are negatively related to ICR. Each ratio has a specific range and it can practically take any value within this range. First category of Quantitative Assessment is Earnings category. Earnings category has a weight of $30 \%$ and consists of five ratios; namely Return on Assets (ROA), Return on Equity (ROE), Cost to Income, Net Interest Margin and Non-Interest Income to Total Income. Return on Assets (ROA) is positively related to ICR and has weight of $25 \%$. It takes values between 0 and 1.50 . Return on Equity (ROE) has also a positive relation with ICR and weight of 25\%, and it stands between 0.3 and 5. Cost to Income Ratio is a number between 55 and 100 . This ratio is negatively related to ICR and has a weight of $30 \%$. Net Interest Margin, with a positive relation to ICR, has a weight of 10\%. It takes values between 0 and 3. Net Interest Income to Total Income is positively related to ICR and has a weight of $10 \%$. Its values are between 0 and 50 .

Capital Adequacy is the second category of Quantitative Assessment with a weight of $20 \%$. It includes four ratios: namely Total Equity to Total Assets, Total Loans to Total Assets, Capital Adequacy Ratio (CAR), and Total Capital to Total Loans. Total Equity to Total Assets ratio, with $30 \%$ weight, has a positive relationship with ICR. It has a range of 0 to 10 . Total Loans to Total Assets ratio, with weight of $20 \%$, is positively related and has a range between 0 and 90 . CAR is positively related to ICR with $30 \%$ weight. It has a range between 0 and 15 . Total Capital to Total Loans ratio, with weight of $20 \%$, is positively related which could be between 0 and 11 .

Liquidity is the third category of Quantitative Assessment. It also consists of four ratios: namely Loans to Customer Deposits, Loans to Total Funding, Liquid Assets to Total Assets, and Customer Deposit to Total Deposit. Loans to Customer Deposits ratio is negatively related and has a weight of $35 \%$. It has a range between 75 and 200. Loans to Total Funding ratio is negatively related and has a weight of $25 \%$. It is between 65 and 110. Liquid Assets to Total Assets ratio is positively related and has a weight of $20 \%$. It is between 0 and 40 . Customer Deposits to Total Deposits is a ratio with $20 \%$ weight and has a positive relation to ICR. It is between 0 and 40 .

Asset Quality is the fourth category of Quantitative Assessment. NPL to Total Loans, Provisions to NPLs (Coverage ratio), Provisions to Operating Income and Portfolio Diversification have been included in this category. NPL to Total Loans ratio has a $25 \%$ weight with a reverse relationship with ICR. It could be between 4 to 20 . Provisions to NPL ratio is positively related with weight of $30 \%$. It could be between 20 to 95 . Provisions to Operating Income ratio is negatively related and weighted by 25\%. It is between 20 and 100. Portfolio Diversification is based on Herfindahl-Hirschman Index (HHI). HHI is a general measure of market concentration. It is calculated as the sum of squared market share of each firm competing in a sector. It can range from zero to 10,000 . According to $\mathrm{HHI}$, Portfolio Diversification can be low, moderate, or high. If $\mathrm{HHI}$ is between 0 and 3.300, it refers to low concentration, if it is between 3.300 and 6.600 it is accepted as moderate concentration and if it is between 6.600 and 10.000 it is accepted as high concentration. In this study, portfolio diversification is a measurement of concentration of a bank in different sectors like agriculture, manufacturing, construction, services, and others.

$\mathrm{HHI}$ is calculated as follows:

$$
\mathrm{HHI}=\mathrm{S}_{\mathrm{a}}+\mathrm{S}_{\mathrm{m}}+\mathrm{S}_{\mathrm{c}}+\mathrm{S}_{\mathrm{s}}+\mathrm{S}_{\mathrm{o}}
$$

Equation 1. HHI: Herfindahl-Hirschman Index

where,

$\mathrm{S}_{\mathrm{a}}$ : Square of portfolio share of agriculture

$\mathrm{S}_{\mathrm{m}}$ : Square of portfolio share of manufacturing

$\mathrm{S}_{\mathrm{c}}$ : Square of portfolio share of construction

$\mathrm{S}_{\mathrm{s}}$ : Square of portfolio share of services

$\mathrm{S}_{\mathrm{o}}$ : Square of portfolio share of other sectors

Management is the fifth and last category of Quantitative Assessment and has a weight of 5\%. It includes of Profit After Tax to Number of Employee ratio and Profit After Tax to Number of Branches. Both ratios are positively related and have weights of 50\%. Qualitative Assessment, second part of ICR, has a 30\% weight in ICR calculation and consists of three assessments; Competitive Position, Audit Report and Ownership with 30\%, 40\% and 30\% weights respectively. First assessment of Qualitative Assessment, Competitive Position, indicates the proportion of total assets of specific bank to total assets of the bank industry. Bank with highest ratio is the Market Leader. The rest accordingly is categorized as High Market Share, Average Market Share and Low Market Share. 
Competitive Position $=\frac{\text { Total Assets of Bank A }}{\text { Total Assets of Banking Sector in Turkey }}$

Equation 2.Qualitative Assessment- Competitive Position

Second assessment of Qualitative Assessment, Audit report, is a statement issued by an internal auditor or an independent external audit company for the user to make decisions based on the results of audit. Audit report is important since this assessment is a declaration of an independent external audit company's statement on the bank. Audit report of banks under study may express three different opinions: "Clean", "Clean with considerable observations" and "Qualified". When financial statements are a fair representation of the bank's financial position, auditor declare financial statements as "Clean Opinion" while if it is "Clean with considerable observations" auditors will have some notes and observations about financial statements. If there were any scope limitations that were imposed upon the auditor's work, auditor opinion expresses a "Qualified Opinion". The reports are mostly with a Clear Opinion and only include a paragraph. If the audit report is qualified, basis for Qualification is normally mentioned after Scope paragraph and before the Opinion paragraph. Opinion paragraph in addition to its standard wording includes "except for the matter described in Basis for Qualification paragraph, the financial statements give true and fair view."

The third and last assessment of Qualitative Assessment is the Ownership of the bank. The ownership could be as "State listed", "State un-listed", "Private listed" and "Private un-listed". A bank could be a state owned or privately owned bank, also it may be listed in Borsa Istanbul Stock Exchange (BIST) or not. Banks that are state owned get a better score because they have Government's support. The fact that they are listed in Borsa Istanbul Stock Exchange (BIST) also affects their score positively since once listed they must be more transparent to the public. Table 1 shows the summary of the above discussion on how to construct ICR rating for any counterparty.

Table 1: All the Categories and weighted Ratios for ICR

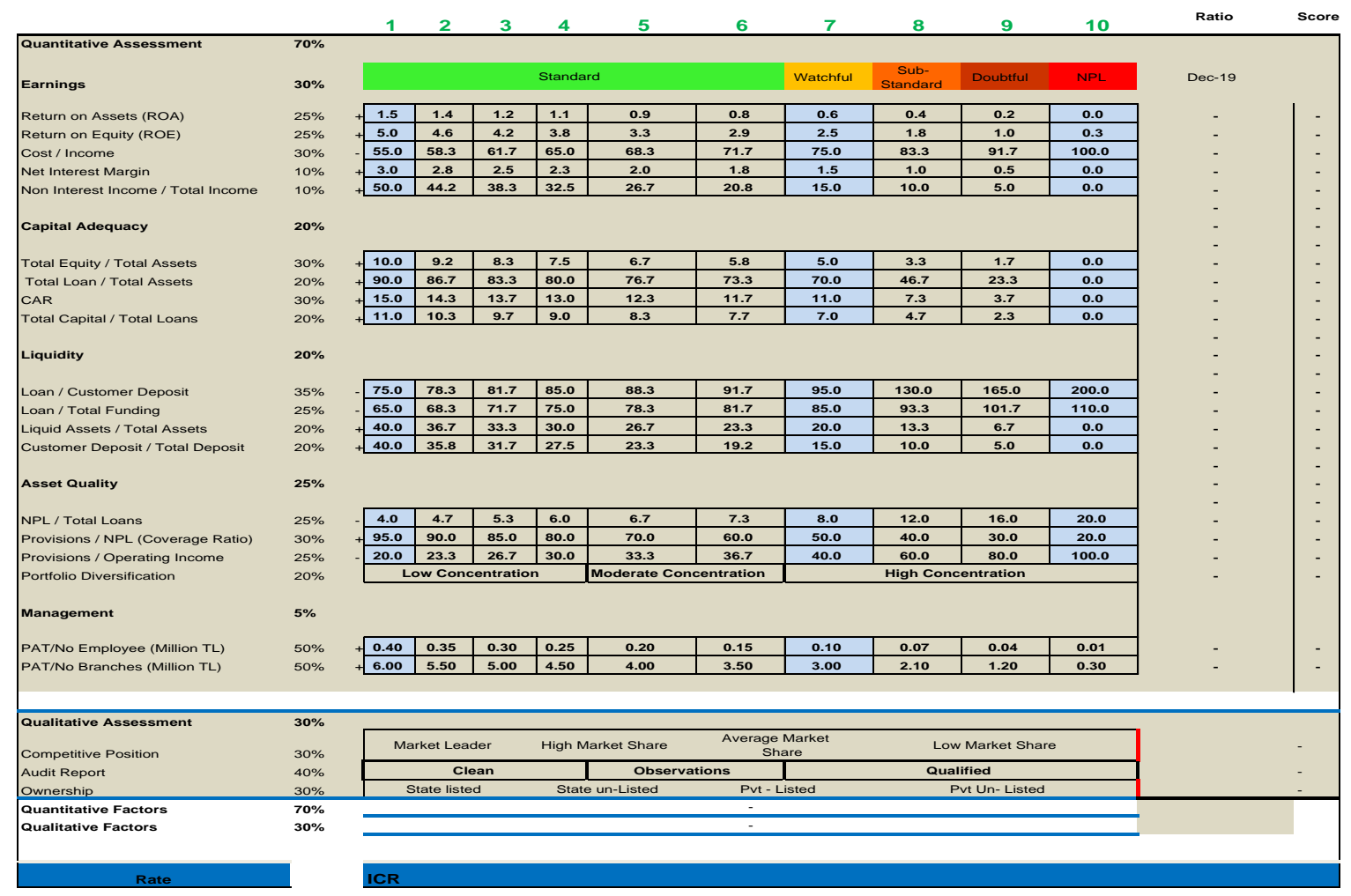




\subsection{Assumptions Under Sensitivity and Scenario Analyses}

Stress Test (ST) is to be conducted on periodic basis, normally once a year. However, for those counter parties where the Internal Credit Rating (ICR) is greater than 4 (ICR > 4), ST may be conducted on semi-annual basis. There are three levels of shocks under sensitivity as well as scenario analysis were used: Minor, Moderate, Major. Minor shock has the lowest level of shock to variable(s) while Major shock has the highest and toughest level of shock to variable (s).

Under the sensitivity analysis, impact of four different changes are analyzed; the rise in NPLs to Total ratio, the decline in Lending rate, the rise in Borrowing rate and depreciation of Turkish Lira (TRY).

Assumption No.1 analyzes the impact of rise in NPLs to Total Loans ratio on Profit after Tax (PAT) while keeping the other variables constant. Under minor shock, impact on Profit after taxes (PAT) is measured assuming that NPLs to Total Loans ratio rises by $5 \%$. On the other hand, under moderate shock, NPLs to Total Loans ratio is assumed to rise by $10 \%$ and under major shock, we assume that NPLs to Total Loans ratio rises by $20 \%$. For instance, if NPLs to Total Loans ratio increases by $5 \%$ it will impact the income statement and balance sheet. In Income statement, Impairment loss on financial assets will rise by this change in NPL. So Net Operating income and Tax provision for continued operations will decrease and finally net income declines.

Basically, with this change, on the left-hand side of balance sheet, Loans decline, NPLs and Provision rise. By the same level of decline in Tax provision for continued operations in income statement, Cash and Balance with central bank will increase. On the right-hand side of balance sheet, Equity will decrease due to a fall in profit.

Assumption No. $2^{2}$ analyzes the impact of declines in Lending rate while keeping the other variables constant. Under minor shock, the impact on Profit after Tax (PAT) is measured when Lending rate declines by $1 \%$. Under moderate shock, Lending rate declines by $2 \%$ and under major shock it declines by $4 \%$. Decreasing Lending rate affects income statement and balance sheet negatively. Therefore, by decreasing $1 \%$ in lending rate, Interest income on loans decreases, which means net income will go down. In balance sheet, cash and profit decrease from Assets side and Liabilities and Equity, respectively.

Assumption No.3 analyzes the impact of rises in Borrowing rate on Profit after Tax (PAT) while keeping the other variables constant. Under minor shock, the impact on PAT is measured when borrowing cost of bank increases by $1 \%$. Similarly, under moderate shock, we assume that the borrowing cost rises by $2 \%$ and under major shock we assume that the borrowing cost rises by $4 \%$. In income statement, increase in borrowing rate affects interest income on deposits. It will increase interest income on deposits. It means borrowing money is more expensive for bank. In the asset side of balance sheet, cash declines and in the Liabilities and Equity side, profit declines.

When Turkish Lira depreciates against USD and Euro it will affect the foreign currency assets and liabilities of the bank. Banks with higher Foreign currency assets will have a better position in case of foreign currency risk. Under minor shock, TRY depreciates by $10 \%$, in case of moderate shock TRY depreciates by $20 \%$ and under major shock TRY depreciates by $100 \%$.

Stress Test under scenario analysis measures the impact on the balance sheet, income statement and Internal credit rating (ICR) of the customer when multiple key variables are changed simultaneously. In order to measure the impact on the financial position of the bank and on its ICR, multiple assumptions under various stressed conditions are tested. Like sensitivity analysis, the impact is measured under three levels of shocks, namely minor, moderate and major shocks.

For scenario analysis, impact on three variables simultaneously have been considered. These variables consist of rise in NPLS to Total Loans ratio, rise in Borrowing interest rate and depreciation in TRY against USD and Euro. Another factor which can be taken as a shock variable is lending rate. However financial institutions normally function in a relatively competitive market; therefore, one institution cannot raise its lending rate regardless of other banks' lending rates. Furthermore, in a relatively competitive market, lending rate is correlated with borrowing rate in a way that the margin between lending and borrowing rates cannot widen aggressively in a short period of time. Having said that when we consider borrowing rate as a shock variable there seems no need to take the other side of the coin (Lending rate) as a separate shock variable. Under minor shock, the impacts on the financials of the bank and on its ICR is determined when NPLs to Total Loans ratio rises by $5 \%$, Borrowing interest rate increases by $1 \%$ and TRY depreciates by $10 \%$ against USD and Euro. Under moderate shock the impacts on the financials of the bank and on its ICR is determined when NPLs to Total Loans ratio rises by $10 \%$, Borrowing interest rate increases by $2 \%$ and TRY depreciates by $20 \%$ against USD and Euro. Under major shock the impacts on the financials of the bank and on its ICR is determined when NPLs rises by $20 \%$, Borrowing interest rate increases by $4 \%$ and TRY depreciates by $100 \%$ against USD and Euro.

\footnotetext{
${ }^{2}$ Market value changes are ignored in this study. Only interest rate impact on income level is measured.
} 


\subsection{Data and Analysis}

Most of the data used in this study has been collected from official sources such as Bank Association of Turkey, Banking Regulation and Supervision Agency (BRSA-BDDK) and official websites of each bank in the sample. Sample includes twelve banks namely Ziraat Bank, Halkbank, İşbank, Vakıflar Bank, Garanti Bank, Yapı ve Kredi Bank, Akbank, QNB Finansbank, Türk Ekonomi Bank, ING Bank, Odea Bank and Şekerbank for the year of 2019.

Two methods for stress testing have been implemented to understand the financial conditions of the twelve Turkish banks: Sensitivity Analysis and Scenario Analysis. Under the first method, only a single variable is changed and its impact on ICR is measured while keeping the other variables constant. In this test, the variables used are Rise in NPLs to Total Loans ratio, Decline in Lending Rate, Rise in Borrowing Rate and Depreciation in TRY against USD and Euro. As it may be obvious, all shocks except last shock are considered as negative shocks. For the last shock, depreciation in TRY against USD and Euro, positive or negative result is not clear cut. The result of such shock depends on whether the foreign currency assets are greater than liabilities or vice versa.

Under the scenario analysis, however, more than one variable is changed and the impact of the scenario on ICR is analyzed. For scenario analysis, the study assumes that there are three levels of shocks: Minor Shock, Moderate Shock and Major Shock. In the study, minor shock means $5 \%$ rise in NPLs to Total Loans ratio, $1 \%$ rise in borrowing interest rate and $10 \%$ depreciation in TRY against USD and Euro. Moderate shock means $10 \%$ rise in NPLs to Total Loans ratio, $2 \%$ rise in borrowing interest rate and $20 \%$ depreciation in TRY against USD and Euro. Major shock means $20 \%$ rise in NPLs to Total Loans ratio, $4 \%$ rise in borrowing interest rate and $100 \%$ depreciation in TRY against USD and Euro.

Internal credit rating is a score between 1 and 10.1 is the best score and 10 is the worst score which shows that a bank has defaulted. ICR for banks can be classified as Standard, Watchful, Sub-standard, Doubtful and NPL which can be represented in numeric terms as follows: $1 \leq I C R<7$ means the bank has a Standard score. $7 \leq I C R<8$ means it has a watchful score. $8 \leq I C R<9$ means it has a doubtful score, and finally, an ICR score between 9 and 10 means the bank has an NPL score.

\section{RESULTS AND DISCUSSIONS}

\subsection{Results: Sensitivity Analysis}

In this section, Internal credit rating (ICR) values before and after stress test simulations have been compared. This comparison has been repeated for all levels of shocks. Before any simulation, QNB Finansbank had the best ICR with a score of 4.05, following it Yapı ve Kredi Bank, Ziraat Bank, ING Bank, Vakıflar Bank, İşbank, Türk Ekonomi Bank, Akbank, Garanti Bank, Halkbank and Odea Bank with scores of 4.37, 4.43, 4.43,4.72, 4.81, 4.89, 4.93, 5.13, 5.22 and 5.72 respectively. Şekerbank in this sample, performed as the worst bank with a score of 7.58. It is already under the watchful status of ICR categories.

Table 2 compares the ICR numbers before the simulation with those after NPLs to Total ratio is changed. It is observed that Şekerbank incurred the least damage by $5.15 \%$ change in its ICR (from 7.58 to 7.97 ) while QNB Finansbank incurred the most adverse effect by $52.10 \%$ change in its ICR (from 4.05 to 6.16). But more importantly, it is apparent that almost all banks reach to the limit of being watchful under the major shock to NPLs Ratio. Garanti Bank becomes watchful for both moderate and major shocks under this analysis. 
Table 2: ICR changes with respect to NPLs rises

\begin{tabular}{|l|c|c|c|c|}
\hline Name of Bank & ICR Before Simulation & $\begin{array}{c}\text { NPL Ratio rises } \\
\mathbf{5} \%\end{array}$ & $\begin{array}{c}\text { NPLs Ratio rises } \\
\mathbf{1 0 \%}\end{array}$ & $\begin{array}{c}\text { NPLs Ratio rises } \\
\mathbf{2 0 \%}\end{array}$ \\
\hline QNB Finansbank & 4.05 & 5.82 & 6.11 & 6.16 \\
\hline apı ve Kredi Bank & 4.37 & 5.82 & 6.10 & 6.19 \\
\hline Ziraat Bank & 4.43 & 6.13 & 6.38 & 6.52 \\
\hline ING Bank & 4.43 & 6.06 & 6.15 & 6.37 \\
\hline Vakıflar Bank & 4.72 & 6.23 & 6.40 & 6.37 \\
\hline Iş̧bank & 4.81 & 6.53 & 6.75 & 6.97 \\
\hline Türk Ekonomi Bank & 4.89 & 6.28 & 6.49 & 6.68 \\
\hline Akbank & 4.93 & 6.65 & 6.77 & 6.95 \\
\hline Garanti Bank & 5.13 & 6.82 & 7.07 & 7.29 \\
\hline Halkbank & 5.22 & 6.57 & 6.76 & 6.73 \\
\hline Odea Bank & 5.72 & 6.41 & 6.60 & 6.61 \\
\hline Şekerbank & 7.58 & 7.91 & 8.08 & 7.97 \\
\hline
\end{tabular}

Figure 1: ICR Changes with respect to NPLs Rises

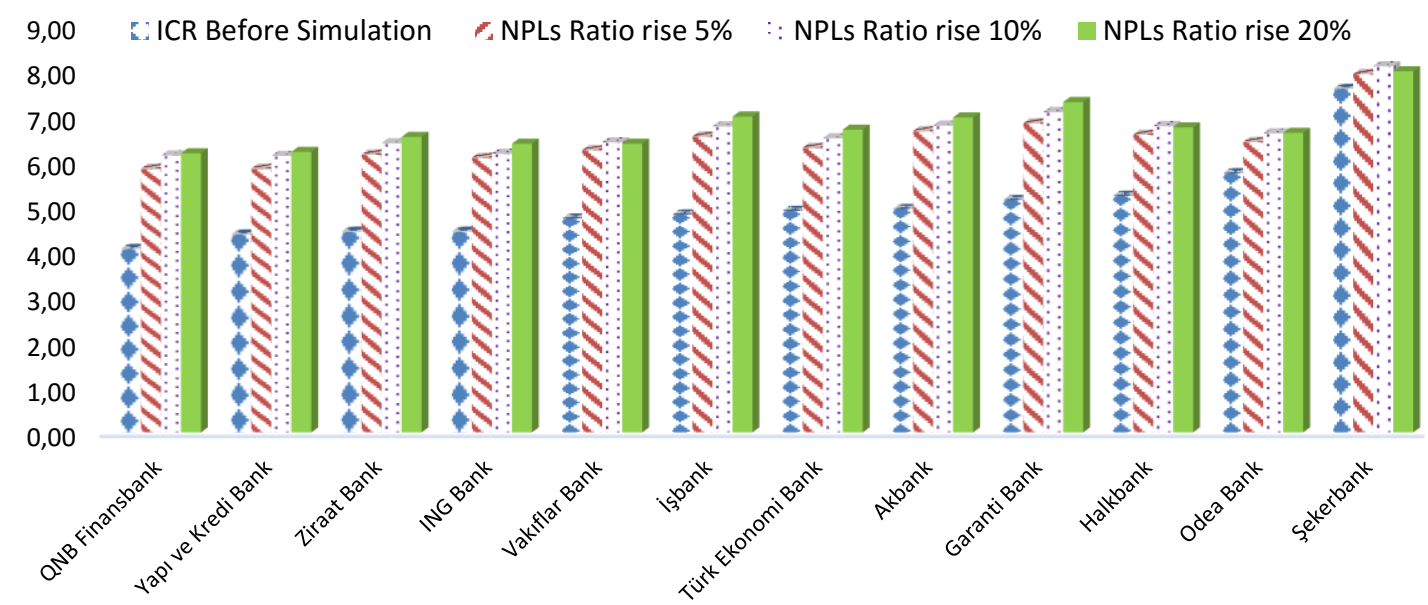

The results in Table 3 indicates that Şekerbank incurred the least damage by $4.49 \%$ change in its ICR (from 7.58 to 7.92 ) while QNB Finansbank incurred the most adverse effect by $36.79 \%$ change in ICR (from 4.05 to 5.54 ) due to Lending rate declines. Moreover, İşbank, Akbank, Garanti Bank, Halkbank, and Odea Bank ICR scores get higher than 6 when a major shock is implemented to Lending Rate. 
Table 3: ICR changes with respect to Lending Rate Declines

\begin{tabular}{|l|c|c|c|c|}
\hline Name of Bank & ICR Before Simulation & $\begin{array}{c}\text { Lending Rate } \\
\text { Decline 1\% }\end{array}$ & $\begin{array}{c}\text { Lending Rate } \\
\text { Decline 2\% }\end{array}$ & $\begin{array}{c}\text { Lending Rate } \\
\text { Decline 4\% }\end{array}$ \\
\hline QNB Finansbank & 4.05 & 4.47 & 5.08 & 5.54 \\
\hline Yapı ve Kredi Bank & 4.37 & 4.97 & 5.42 & 5.63 \\
\hline Ziraat Bank & 4.43 & 5.03 & 5.49 & 5.70 \\
\hline ING Bank & 4.43 & 4.47 & 4.62 & 5.24 \\
\hline Vakıflar Bank & 4.72 & 5.60 & 5.73 & 5.92 \\
\hline Işbank & 4.81 & 5.20 & 5.92 & 6.13 \\
\hline Türk Ekonomi Bank & 4.89 & 5.11 & 5.81 & 5.85 \\
\hline Akbank & 4.93 & 5.25 & 5.73 & 6.41 \\
\hline Garanti Bank & 5.13 & 5.55 & 6.10 & 6.63 \\
\hline Halkbank & 5.22 & 5.96 & 6.05 & 6.11 \\
\hline Odea Bank & 5.72 & 6.00 & 6.17 & 6.34 \\
\hline Şekerbank & 7.58 & 7.58 & 7.71 & 7.92 \\
\hline
\end{tabular}

Figure 2: ICR Changes with respect to Lending Rate Declines

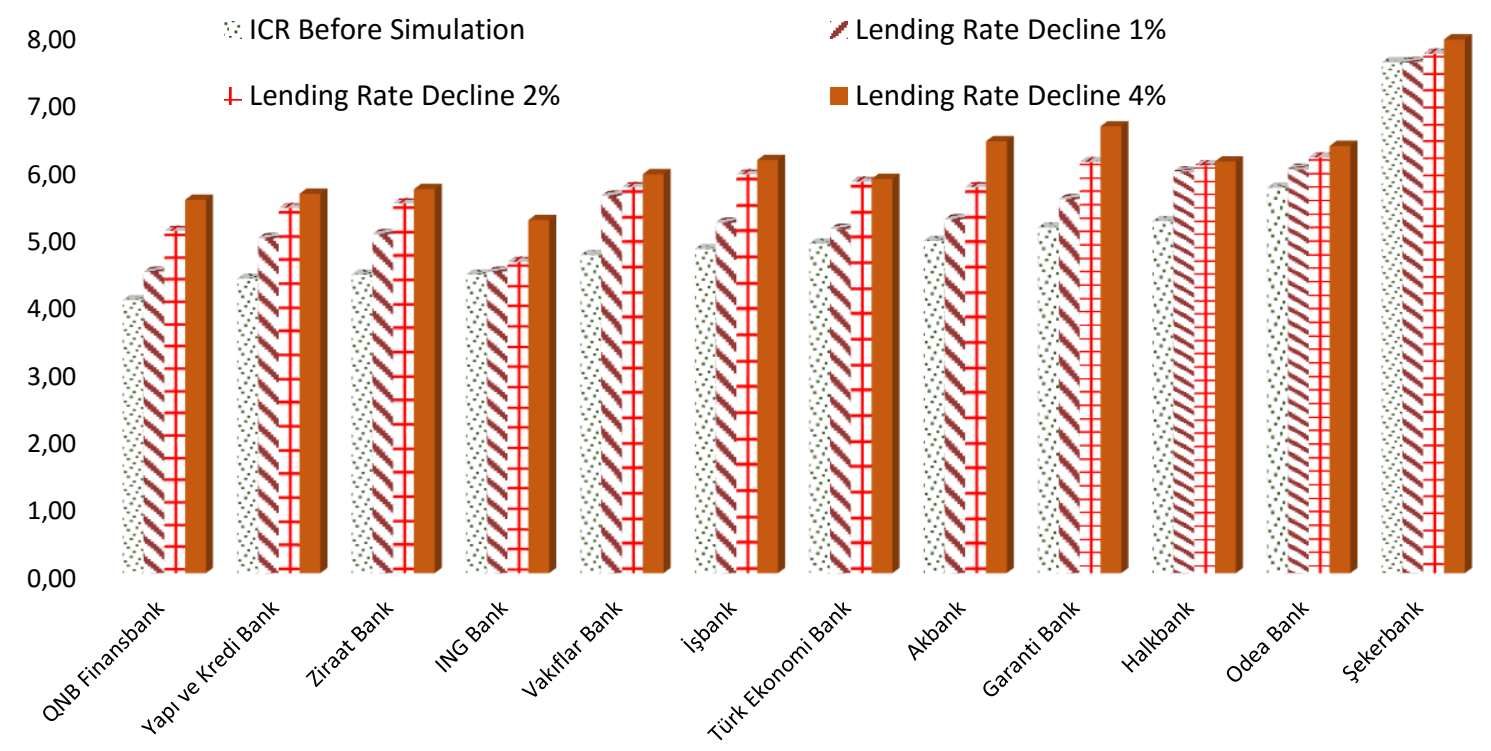

Similar to Lending Rate shock, Borrowing Rate shock makes the least damage to Şekerbank ICR score (with a 3.69\% change from 7.58 to 7.86) while the most adverse effect on QNB Finansbank (with a $35.80 \%$ change from 4.05 to 5.50 ). Additionally, İşbank, Akbank, Garanti Bank, Halkbank, and Odea Bank ICR scores get higher than 6 with the major shock to Lending Rate (Table 4). 
Table 4: ICR changes with respect to Borrowing Rate Rises

\begin{tabular}{|l|c|c|c|c|}
\hline Name of Bank & ICR Before Simulation & $\begin{array}{c}\text { Borrowing Rate } \\
\text { Rise 1\% }\end{array}$ & $\begin{array}{c}\text { Borrowing } \\
\text { Rate Rise 2\% }\end{array}$ & $\begin{array}{c}\text { Borrowing } \\
\text { Rate Rise 4\% }\end{array}$ \\
\hline QNB Finansbank & 4.05 & 4.42 & 4.68 & 5.50 \\
\hline Yapı ve Kredi Bank & 4.37 & 4.80 & 5.37 & 5.52 \\
\hline Ziraat Bank & 4.43 & 4.96 & 5.47 & 5.70 \\
\hline ING Bank & 4.43 & 4.47 & 4.62 & 5.38 \\
\hline Vakıflar Bank & 4.72 & 5.37 & 5.66 & 5.79 \\
\hline İşbank & 4.81 & 5.20 & 5.87 & 6.09 \\
\hline Türk Ekonomi Bank & 4.89 & 5.13 & 5.83 & 5.87 \\
\hline Akbank & 4.93 & 5.25 & 5.80 & 6.37 \\
\hline Garanti Bank & 5.13 & 5.43 & 5.92 & 6.52 \\
\hline Halkbank & 5.22 & 5.94 & 5.98 & 6.11 \\
\hline Odea Bank & 5.72 & 6.02 & 6.15 & 6.28 \\
\hline Şekerbank & 7.58 & 7.58 & 7.67 & 7.86 \\
\hline
\end{tabular}

Figure 3: ICR changes with respect to Borrowing Rate Rises

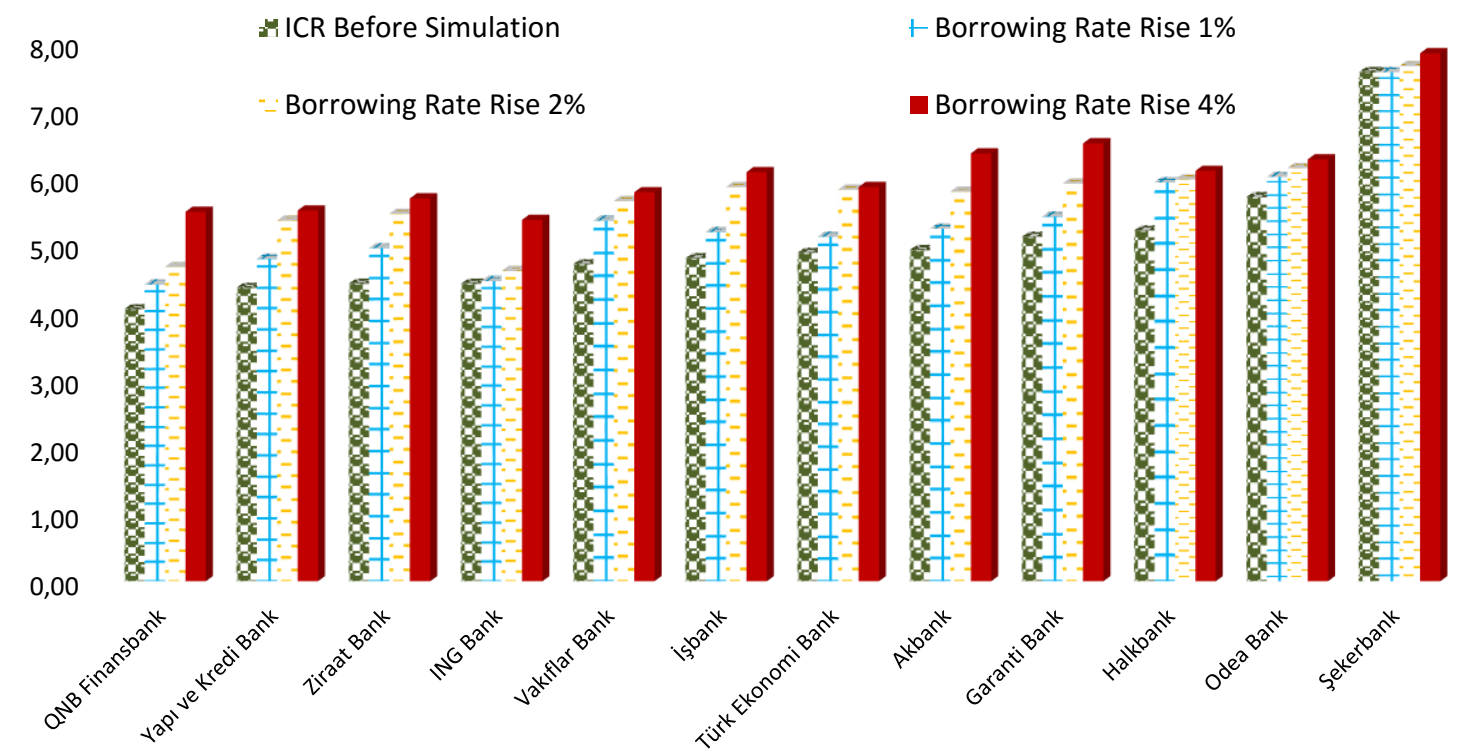

Table 5 compares the current ICRs with those under the assumption that TRY depreciates by $10 \%, 20 \%$ and $100 \%$. The results indicate that Şekerbank experiences a $1.19 \%$ change in its ICR score (from 7.58 to 7.86) while QNB Finansbank incurs the most adverse effect by a $34.57 \%$ change in its ICR (from 4.05 to 5.45). The major shock to TRY rises the ICR scores of işbank, Akbank, Garanti Bank, and TEB Bank over 6. 
Table 5: ICR Changes with respect to TRY Depreciation

\begin{tabular}{|l|c|c|c|c|}
\hline Name of Bank & ICR Before Simulation & $\begin{array}{c}\text { Depreciation in } \\
\text { TRY 10\% }\end{array}$ & $\begin{array}{c}\text { Depreciation in } \\
\text { TRY 20\% }\end{array}$ & $\begin{array}{c}\text { Depreciation in } \\
\text { TRY 100\% }\end{array}$ \\
\hline QNB Finansbank & 4.05 & 4.84 & 4.68 & 5.45 \\
\hline Yapı ve Kredi Bank & 4.37 & 5.03 & 5.29 & 5.54 \\
\hline Ziraat Bank & 4.43 & 4.85 & 5.38 & 5.59 \\
\hline ING Bank & 4.43 & 4.49 & 4.63 & 5.79 \\
\hline Vakıflar Bank & 4.72 & 5.37 & 5.50 & 5.66 \\
\hline İşbank & 4.81 & 5.14 & 5.86 & 6.07 \\
\hline Türk Ekonomi Bank & 4.89 & 5.70 & 5.79 & 6.00 \\
\hline Akbank & 4.93 & 5.25 & 5.81 & 6.22 \\
\hline Garanti Bank & 5.13 & 5.44 & 6.04 & 6.48 \\
\hline Halkbank & 5.22 & 5.70 & 5.81 & 5.90 \\
\hline Odea Bank & 5.72 & 5.84 & 5.96 & 5.98 \\
\hline Şekerbank & 7.58 & 7.58 & 7.58 & 7.67 \\
\hline
\end{tabular}

Figure 4: ICR Changes with respect to TRY Depreciation

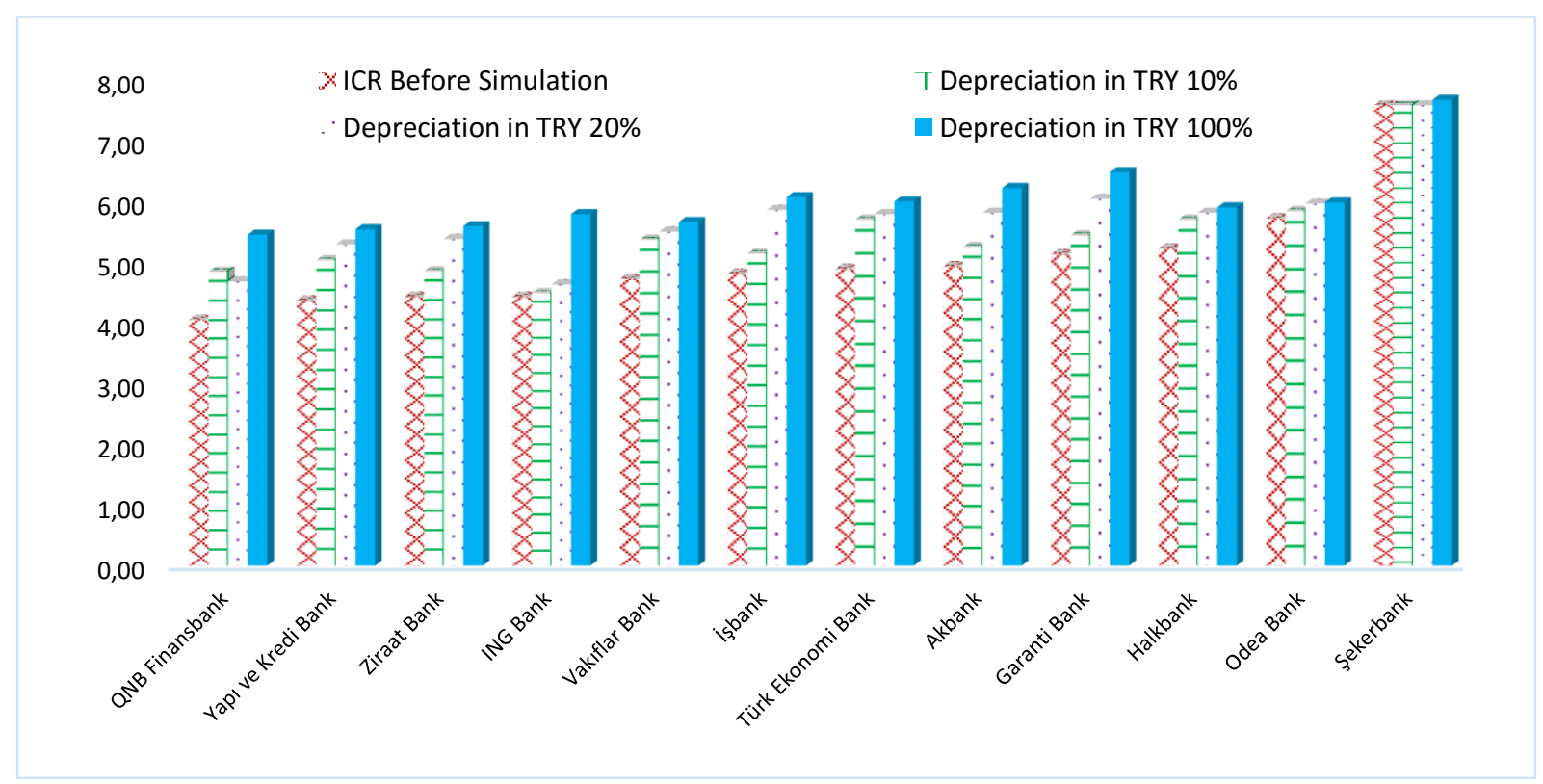

\subsection{Results: Comprehensive Scenario Analysis}

Table 6 shows the summary results of the shocks for the scenario analysis which assumes Rise in NPLs to Total Loans ratio, Borrowing Interest Rate and Depreciation in TRY against USD and Euro simultaneously. The last column of the table shows the effect of a Major shock in Scenario Analysis; NPLs to Total Loans Ratio rises 20\%, Borrowing Interest Rate rises $4 \%$ and $100 \%$ depreciation in TRY. When the ICR numbers after a major shock are compared to ICRs before simulation, it is observed 
that Şekerbank incurred the least damage by these sets of shocks with a $7.26 \%$ change in its ICR (from 7.58 to 8.13 ) while QNB Finansbank incurred the most adverse effect with a 53.33\% change in its ICR (from 4.05 to 6.21).

As it it is indicated by dashed line in Figure 5, it is interesting that İşbank, Akbank, Garanti Bank, and Halkbank ICR scores gets quite close to watchful status even under the minor shock scenario. Garanti Bank becomes watchful under moderate shock and iş̧bank, and Akbank joins to Garanti Bank under the major shock scenario. For all other banks ICR scores are over 6 under the major shock scenario. Even if Şekerbank is the bank which is least affected, it is the one that transfer from watchful to doubtful for both moderate and major shock cases. In short, the positions of all Turkish banks look problematic under the scenario analysis.

Table 6: Internal Credit Rating First Sub-Scenario Analysis Simulation

\begin{tabular}{|c|c|c|c|c|}
\hline \multirow[b]{2}{*}{ Name of Bank } & \multirow[b]{2}{*}{$\begin{array}{l}\text { ICR Before } \\
\text { Simulation }\end{array}$} & \multicolumn{3}{|c|}{ Scenario Analysis: ICR After Simulation } \\
\hline & & $\begin{array}{c}\text { Minor Shock: NPLs } \\
\text { Rise 5\%, Borrowing } \\
\text { Interest Rate Rise } \\
\text { 1\%, TRY Depreciate } \\
10 \%\end{array}$ & $\begin{array}{c}\text { Moderate Shock: NPLs } \\
\text { Rise } 10 \% \text {, Borrowing } \\
\text { Interest Rate Rise } 2 \% \text {, } \\
\text { TRY Depreciate } 20 \%\end{array}$ & $\begin{array}{l}\text { Major Shock: NPLs Rise } \\
\text { 20\%, Borrowing } \\
\text { Interest Rate Rise } 4 \% \text {, } \\
\text { TRY Depreciate } 100 \%\end{array}$ \\
\hline QNB Finansbank & 4.05 & 5.92 & 6.16 & 6.21 \\
\hline Yapı ve Kredi Bank & 4.37 & 5.86 & 6.16 & 6.25 \\
\hline Ziraat Bank & 4.43 & 6.17 & 6.44 & 6.59 \\
\hline ING Bank & 4.43 & 6.06 & 6.26 & 6.48 \\
\hline Vakıflar Bank & 4.72 & 6.25 & 6.50 & 6.57 \\
\hline İşbank & 4.81 & 6.54 & 6.91 & 7.06 \\
\hline Türk Ekonomi Bank & 4.89 & 6.33 & 6.60 & 6.68 \\
\hline Akbank & 4.93 & 6.67 & 6.89 & 7.21 \\
\hline Garanti Bank & 5.13 & 6.79 & 7.20 & 7.33 \\
\hline Halkbank & 5.22 & 6.70 & 6.89 & 6.97 \\
\hline Odea Bank & 5.72 & 6.47 & 6.75 & 6.83 \\
\hline Şekerbank & 7.58 & 7.95 & 8.07 & 8.13 \\
\hline
\end{tabular}




\section{Figure 5: Internal Credit Rate after Scenario Analysis Simulation}

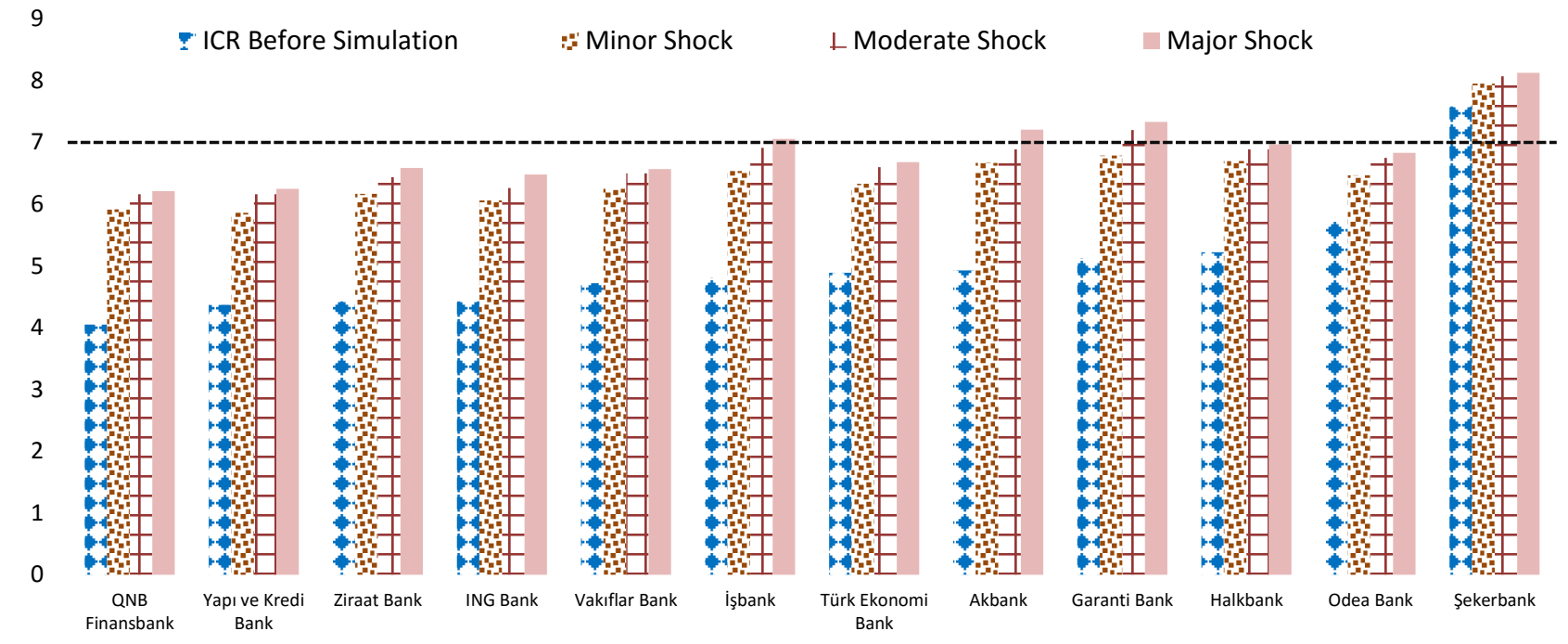

The graph summarizes the results for all types of scenario analyses for all banks. Top corner shows the ICR values before simulation, right corner stands for minor shock, bottom corner stands for moderate shock and finally the left corner stands for the major shock. The graph shows, diamond created by Şekerbank's ICR rates encompasses all the other banks' ICR diamonds. This means that this bank was the one with worst ICR rates in all circumstances, namely for before simulation, under Minor shock, Moderate shock, and Major shock. As the inner diamond illustrates, QNB Finansbank stands as the first rank in all levels of shock and has the lowest ICR rate (4.05) before simulation. The graph also shows that all banks' ICR are above six for moderate and major shocks.

\section{Figure 6: Scenario Analysis After All Level Shock}
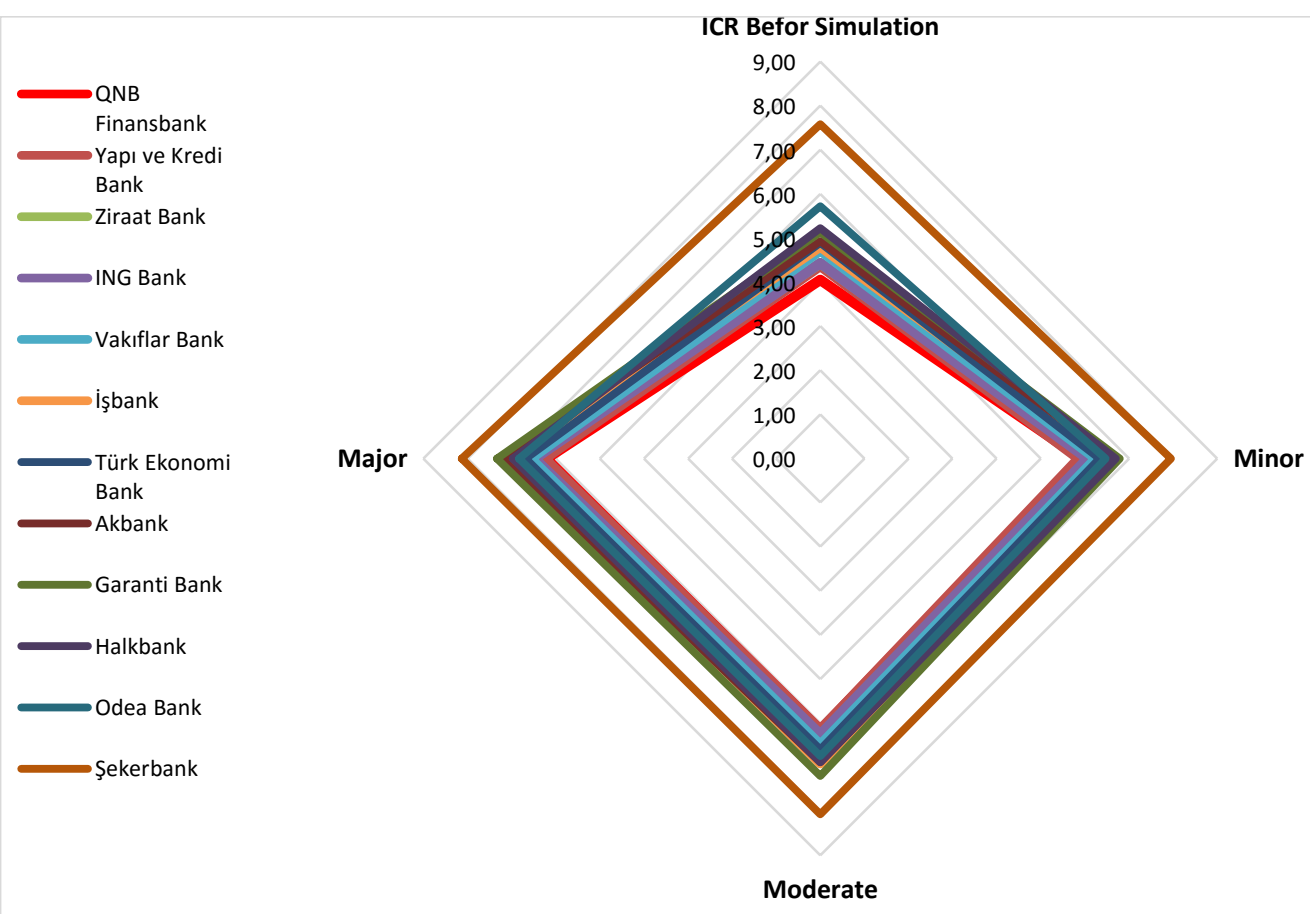
Now the question, for which the answer is not simple and plain, that which shock has the most significant effect on the banks may be asked. The following discussion will try to clarify this issue. First, it should be noticed that not all of shocks has exerted an effect on the banks in a similar manner. But the main factor that affected the banks in worst manner has been "Rise in NPLs ratio". The banks with their ICR change in percentage following a major shock of rise in NPLs ratio given in parentheses, are as follows: QNB Finansbank (52.10\%), Yapı ve Kredi Bank (41.65\%), Ziraat Bank (47.21\%), ING Bank (43.79\%), Vakıflar Bank (34.96\%), İşbank (44.93\%), Türk Ekonomi Bank (36.61\%), Akbank (40.97\%), Garanti Bank (42.11\%), Halkbank (28.85\%), Odea Bank (15.56\%) and finally, Şekerbank (5.15\%). Thus, it looks like Rise in NPLs ratio is quite critical factor affecting the resilience of the banks. Subsequently, the specific shocks which have created the highest percentage change in ICR of a bank have been chosen to create the following table:

Table 7: Percentage changes in ICR ratings with respect to Various Factor Changes

\begin{tabular}{|l|c|c|c|c|c|c|}
\hline Bank & $\begin{array}{c}\text { Rise in NPLs } \\
\text { to Total Loans } \\
\text { Ratio by 20\% } \\
(-)\end{array}$ & $\begin{array}{c}\text { Decline in } \\
\text { Lending } \\
\text { Rate by } \\
\mathbf{4 \%}(-)\end{array}$ & $\begin{array}{c}\text { Borrowing } \\
\text { Rate Rise by } \\
\mathbf{4} \%(-)\end{array}$ & $\begin{array}{c}\text { TRY } \\
\text { Depreciation } \\
\mathbf{( 1 0 0 \% )}\end{array}$ & Maximum & Shock \\
\hline QNB Finansbank & $52.10 \%$ & $36.79 \%$ & $35.80 \%$ & $34.57 \%$ & $52.10 \%$ & Rise in NPLs Ratio \\
\hline Yapı ve Kredi Bank & $41.65 \%$ & $28.83 \%$ & $26.32 \%$ & $26.77 \%$ & $41.65 \%$ & Rise in NPLs Ratio \\
\hline Ziraat Bank & $47.21 \%$ & $28.70 \%$ & $28.70 \%$ & $26.21 \%$ & $47.21 \%$ & Rise in NPLs Ratio \\
\hline ING Bank & $43.79 \%$ & $18.28 \%$ & $21.44 \%$ & $30.70 \%$ & $43.79 \%$ & Rise in NPLs Ratio \\
\hline Vakıflar Bank & $34.96 \%$ & $25.42 \%$ & $22.67 \%$ & $19.92 \%$ & $34.96 \%$ & Rise in NPLs Ratio \\
\hline İşbank & $44.93 \%$ & $27.46 \%$ & $26.63 \%$ & $26.22 \%$ & $44.93 \%$ & Rise in NPLs Ratio \\
\hline Türk Ekonomi Bank & $36.61 \%$ & $19.63 \%$ & $20.04 \%$ & $22.70 \%$ & $36.61 \%$ & Rise in NPLs Ratio \\
\hline Akbank & $40.97 \%$ & $30.02 \%$ & $29.21 \%$ & $26.17 \%$ & $40.97 \%$ & Rise in NPLs Ratio \\
\hline Garanti Bank & $42.11 \%$ & $29.24 \%$ & $27.10 \%$ & $26.32 \%$ & $42.11 \%$ & Rise in NPLs Ratio \\
\hline Halkbank & $28.85 \%$ & $16.98 \%$ & $16.98 \%$ & $12.96 \%$ & $28.85 \%$ & Rise in NPLs Ratio \\
\hline Odea Bank & $15.56 \%$ & $10.84 \%$ & $9.79 \%$ & $4.55 \%$ & $15.56 \%$ & Rise in NPLs Ratio \\
\hline Şekerbank & $5.15 \%$ & $4.49 \%$ & $3.69 \%$ & $1.19 \%$ & $5.15 \%$ & Rise in NPLs Ratio \\
\hline
\end{tabular}

Note: The table shows us the most significant factor affecting the ICR of a bank is NPLs Ratio.

\section{CONCLUSION}

This study examines the performance and financial vulnerability of twelve Turkish banks for 2019. For that purpose, three state-owned deposit banks, five private deposit banks and four foreign banks are chosen as the sample. Stress Testing method as a risk management tool and Internal Credit Rating (ICR) as a performance measurement tool have been used to assess the vulnerability of banks to exceptional events. Stress testing identifies the impact of extreme expected and unexpected shocks to a bank's capital, provides an assessment of its financial strength to withstand to shocks and to spot emerging risk(s) and uncover weak spots in the financial institution. It enables banks in identifying their vulnerabilities at an early stage. To analyze the banks by stress testing, each bank has been given a rating based on two parts, one quantitative assessment and the other qualitative assessment: Internal credit rating (ICR). Current ICR ratings of banks have been compared to those under stress testing.

Results showed that before stress testing, all banks are within the standard classification of ICR rating except for Şekerbank for which ICR (7.58) is at "Sub-standard" category. However, under the stress testing not all banks are resilient to all types of shocks. When scenario analyses are implemented for the three levels of shock, ICR of some the banks move to "Watchful", "Sub-standard" and "Doubtful" categories. In case of minor shock, all banks except QNB Finansbank and Yapı ve Kredi Bank downgrade from "Standard" category to "Watchful" category. Şekerbank stands at "Sub-standard" category. In case of moderate shock, ICR for Garanti Bank moves to the "Sub-standard" category and ICR for Şekerbank moves to "Doubtful" category while for the rest of banks, ICR move to "Watchful" category. In the case of Major shock, ICR for Isşbank, Akbank and 
Garanti Bank move from "Standard" category to "Sub-standard" category. ICR for Şekerbank move from "Sub-standard" category to "Doubtful" category. ICR for the move from "Standard" category to "Watchful" category.

This study shows that Turkish banks are on the knife edge. The results show that the critical factor that may result in the insolvency of the banks is NPLs. Thus, Turkish regulators should take necessary measures to protect Turkish banks against any possible shocks that may occur due to the COVID-19 crisis experienced currently. These measures, in the short run, should support banks to prevent their current loans becoming non-performing ones. But also, the regulators should be quite careful about that the measures taken to overcome the crisis should not cause new problems like increasing non-performing loans in the long run, either.

\section{REFERENCES}

Akbank Website. (n.d.). Retrieved from http://www.akbank.com/en-us/investor-relations/Pages/Financials.aspx

Başarır, C. (2016). A Macro Stress Test Model of Credit Risk for the Turkish Banking Sector. Asian Economic and Financial Review , 6 (12), 762-774.

Başarir, C., \& Toraman, C. (2014). Financial Stability Analysis in Banking Sector: A Stress Test Method. Muhasebe ve Finansman Dergisi (62), 129-144.

Bangladesh Bank Department of Offsite Supervision. (2010). Guideline on Stress Testing. Bangladesh: Bangladesh Bank Department of Offsite Supervision.

Banking Regulation and Supervision Agency - BDDK. (n.d.). Retrieved from https://www.bddk.org.tr/WebSitesi/English.aspx

Basel Committee on Banking Supervision. (2017). Supervisory and bank stress testing: range of practices. Bank for international Settlement.

Cakmak, B. (2014). A Stress Testing Framework for The Turkish Banking Sector: An Augmented Approach. Middle East Technical University, The Graduate School of Social Sciences. Ankara: Middle East Technical University.

Committee of European Banking Supervisors. (2010). CEBS Guidelines on Stress Testing (GL32). Committee of European Banking Supervisors.

European Banking Authority . (2018). Guidelines On Institutions' Stress Testing. European Banking Authority .

Filosa, R. (2007). Stress testing of the stability of the Italian banking system: a VAR approach.

Fungáčová, Z., \& Jakubík, P. (2012). Bank Stress Tests as an Information Device for Emerging Markets: The Case of Russia. Charles University, Institute of Economic Studies, Faculty of Social Sciences. Prague: Charles University .

Garanti Bank Website. (n.d.). Retrieved from https://www.garanti.com.tr/en/our_company/investor_relations.page

Halkbank Website. (n.d.). Retrieved from https://www.halkbank.com.tr/en/international-banking/83/financialreports?AspxAutoDetectCookieSupport=1

Hoggarth, G., Sorensen, S., \& Zicchino, L. (2005). Stress Tests of UK Banks Using a VAR Approach. Bank of England . London: Bank of England İşbank Website. (n.d.). Retrieved from https://www.isbank.com.tr/EN/about-isbank/investor-relations/publications-and-results/financialstatements/Pages/financial-statements.aspx

ING Bank Website. (n.d.). Retrieved from https://www.ing.com/Investor-relations/Financial-performance/Annual-reports.htm

Kamenik, O., Tuma, Z., Vavra, D., \& Smidova, Z. (2013). A simple Fiscal Stress Testing Model: Case Studies of Astrian, Czech and German Economies. OECD, ECONOMICS DEPARTMENT WORKING PAPERS No. 1074 . OECD.

Mohsin, M., \& Kamal, M. (2012). Managing Stress Test for Banks: A Case Study on Ten Commercial Banks In Bangladesh. IOSR Journal of Business and Management (IOSRJBM) , 2 (5), 11-23.

Odea Bank Website. (n.d.). Retrieved from https://www.odeabank.com.tr/en-us/about-odeabank/reports/sayfalar/annual-reports.aspx

Office of Superintendent of Financial Institutions of Canada (OSFI). (2009). Guideline on Stress Testing. Office of Superintendent of Financial Institutions of Canada.

Onder, S., Damar, B., \& Hekimoglu, A. A. (2015). Macro Stress Testing and an Application on Turkish Banking Sector. Procedia Economics and Finance, 38, 17-37. 
Otani, A., Shiratsuka, S., Tsurui, R., \& Yamada , T. (2009). Macro Stress-Testing on the Loan Portfolio of Japanese Banks. Bank of Japan (BoJ). Tokyo : Bank of Japan Working Paper Series.

Public Disclosure Platform. (N.D.). Retrieved from httPs://WWW.KAP.ORg.tR/en/SekTORLeR

QNB Finansbank Website. (n.d.). Retrieved from https://www.qnbfinansbank.com/en/investor-relations/financial-information

State Bank of Pakistan . (2012). Guidelines on Stress Testing. Banking Surveillance Department. State Bank of Pakistan.

Şekerbank Website. (n.d.). Retrieved from http://www.sekerbank.com/en/investorrelations/statements

Türk Ekonomi Bank (TED) Website. (n.d.). Retrieved from https://www.teb.com.tr/about-teb/annual-reports/

The Banks Association of Turkey. (n.d.). Retrieved from https://www.tbb.org.tr/tr

Vakıfbank Website. (n.d.). Retrieved from https://www.vakifbank.com.tr/tas-bank-only.aspx?pagelD=644

Virolainen, K. (2004). Macro stress testing with a macroeconomic credit risk model for Finland. Bank of Finland, Research Department. Bank of Finland.

Vukelí c, T. (2011). Stress Testing of the Banking Sector in Emerging Markets: A Case of the Selected Balkan Countries. Charles University, Faculty of Social Sciences, Institute of Economic Studies. Prague: Charles University.

Yapıkredi Bank Website. (n.d.). Retrieved from https://www.yapikredi.com.tr/en/investor-relations/financials\#f1-tab2

Zeman, J., \& Jurca, P. (2008). Macro Stress Testing of Slovak Banking Sector. Working Paper, National Bank of Slovakia.

Ziraat Bank Website. (n.d.). Retrieved from

https://www.ziraatbank.com.tr/en/InvestorRelations/Financials/Pages/AuditReportAndFinancialStatements.aspx 